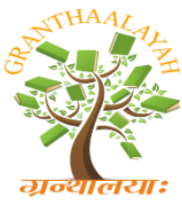

INTERNATIONAL JOURNAL OF RESEARCH GRANTHAALAYAH A knowledge Repository

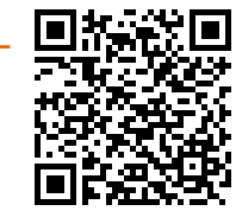

Social

\title{
AWARENESS OF E-LEARNING AMONG PROSPECTIVE TEACHER EDUCATORS (M.Ed. SCHOLARS)
}

\author{
Dr.C.Shankar ${ }^{* 1}$ \\ (M.Sc., M.Ed., M.Ed (SE)., M.Phil., NET., NET., Ph.D.) \\ ${ }^{* 1}$ Assistant Professor in Education, K.R.P. College of Education, Sankari West-637303, \\ Namakkal District, India
}

DOI: https://doi.org/10.29121/granthaalayah.v5.i1(SE).2017.1923

\begin{abstract}
Prospective Teacher Educators (M.Ed scholars) using e-learning is more crucial than acquiring a large number of computers. Prospective teacher educators have to be trained to facilitate the learning process, make the process real, achievable, challenging, yet exciting and not intimidating. Everything need not be written on the blackboard to be considered as taught. Prospective teacher educators think that the computer is used only to make the content look attractive. They need to know that in 21 st century, information is not difficult access, instead organizing, sharing, and collaborating become essential skills. The present generation is a multimedia generation. They are numbed by too much of information and easy access to that information. The information that is given in the classroom is redundant and presented in boring manner. They show so much of the present and the past far and wide that one seems to learn unknowingly. So a study is intended to study about the level of awareness of e-learning among prospective teacher educators. The investigator selected normative methodology and survey technique for the present study based on the problem selected. For that a sample of 306 number of prospective teacher educators was selected for the present study. Descriptive and inferential techniques were used for the present study. It was found that the level of awareness of e-learning of prospective teacher educators was average. Independent variables like gender, nature of subject has significant influence on the awareness of prospective teacher educators. Other independent variables like medium of instruction, educational qualification, marital status, location and type of family has least significant influence over the awareness of e-learning among prospective teacher educators. So it is necessary to revamp the existing policies to improve e-learning among the prospective teacher educators during their pre-service training programme.
\end{abstract}

Keywords: E-Learning; Communication; Study Materials; Teachers \& Students.

Cite This Article: Dr.C.Shankar. (2017). "AWARENESS OF E-LEARNING AMONG PROSPECTIVE TEACHER EDUCATORS (M.Ed. SCHOLARS)." International Journal of Research - Granthaalayah, 5(1)SE, 62-67. 10.29121/granthaalayah.v5.i1(SE).2017.1923. 


\section{Introduction}

E-learning involves delivery of content and resources for teaching and learning via different communication protocols. E-Learning mechanism involves a variety of professionals such as Instructional Designers, Course Writers/Content Creator, Reviewers, Graphic Designers and Knowledge Organizers/Library and Information Professionals. Simply, e-learning is the mixture of technology and education. E-Learning is an environment in which the lectures and educational content are deployed on CDs or Web Servers. Facilities are provided for interaction with the media and direct discussions with the teachers through net meeting or chatting. E-Learning embodies many factors such as almost all agree that e-Learning is of strategic importance. Almost all also agree that e-Learning is an effective method that should be blended into a corporation's current learning mix. E-Learning refers to the use of internet or wireless technologies to deliver abroad array of training solutions. E-Learners access the learning from computers via the internet or an intranet, or through a hand held device like a palm pilot.

\section{Statement}

The statement of the present problem is entitled as "Awareness of e-learning among Prospective Teacher Educators (M.Ed scholars).”

\section{Objectives of the Study}

- To know the level of awareness of e-learning of Prospective Teacher Educators

- To find the level of awareness of e-learning of Prospective Teacher Educators based on the select sub sample.

\section{Hypotheses of the Study}

- The level of awareness of e-learning among Prospective Teacher Educators is low.

- Prospective Teacher Educators do not differ significantly in their awareness of elearning based on the select sub sample.

\section{Method Used for the Study}

Based on the problem, the investigator selected normative methodology and survey technique for the present study.

\section{Sample and Sampling Technique}

The Population for the present Study Consist of Prospective Teacher Educators studying in Namakkal and Salem districts of Tamilnadu. The investigator used Stratified random technique for the study for the present problem with respect to nature of college. Thus, a total of 306 numbers of Prospective Teacher Educators (sample) was selected for the present study. 


\section{Description of the Tool}

The awareness of e-learning statement was adapted from (Amuthavalli,2008) and it was modified by the investigator with the help of experts and pilot study was carried out in order to make it a standardized one.

\section{Reliability and Validy}

The reliability of the test by split-half technique followed by the use of Spearman-Brown prophecy formula is found to be 0.630 . The significance of the reliability was tested with ' $t$ ' test. The' t' value 4.291 was significant at 0.01 level. Thus the reliability was highly significant at 0.01 level. The intrinsic validity is also called as the index of reliability (Guilford 1954).The formula to be used to determine the intrinsic validity is the square root of its reliability. Thus the validity of this test is 0.793 . The significance of the validity was tested with ' $t$ ' test. The ' $t$ ' value 6.88 was significant at 0.01 level. Therefore, the validity was significant at 0.01 level. Thus from the two co-efficient it may be inferred that this test is highly reliable and valid.

\section{Scoring Procedure}

Awareness of e-learning scale consisted of 30 statements with 5 point rating scale. For the positive statements, the marks are given as 5,4,3,2,1 for the options strongly agree, agree, undecided, disagree, strongly disagree and reversed in the case of negative statements.

\section{Norms of the Tool}

After getting discussion with the subject experts and jury opinion, the of Awareness of e-learning was segregated into high, average and low awareness based on the $M \pm 1 \sigma$ (mean \pm 1 standard deviation) area distribution properties of the normal probability curve which contributes $68.26 \%$ in its total distribution.

\section{Statical Technique Used in the Study}

Descriptive and inferential techniques were used for the present study.

\section{Descriptive Statistics}

Hypothesis 1 The level of Awareness of e-learning among Prospective Teacher Educators is low.

Table 1: Shows the Mean, S.D, Skewness and kurtosis value of awareness of e-learning of Prospective Teacher Educators

\begin{tabular}{|l|l|l|l|l|l|l|}
\hline e-learning & $\mathbf{N}$ & Mean & S.D & Skewness & Kurtosis & $\begin{array}{l}\text { Level of } \\
\text { Significance }\end{array}$ \\
\hline Awareness & 306 & 110.83 & 18.929 & 0.605 & 2.672 & Average \\
\hline
\end{tabular}


From the above Table.1, it is shown that the mean and S.D scores of awareness among e-learning of Prospective Teacher Educators are 110.83 and 18.929. The mean value 110.83 is found within the range of mean $\pm 1 \sigma$. Therefore, the level of awareness of e-learning among Prospective Teacher Educators is found as average. The skewness value is found to be positive (0.605).It indicates that nature of distribution of the curve is lightly skewed on the right side. The positive kurtosis value (2.672) indicates that the height of the curve is found to be lepto kurtic in nature. The level of awareness among e-learning of Prospective Teacher Educators is average.

\section{Differential Analysis}

Differential analysis is an important procedure by which the researcher is able to make inferences involving the determination of the statistical significance of difference between groups with reference to selected variables. It involves the use of ' $t$ ' test and ' $F$ ' test.

Hypothesis 2 Prospective Teacher Educators do not differ significantly in their awareness of elearning based on the select sub samples.

Table 2: Shows the Mean, S.D, t-values of awareness of e-learning of Prospective Teacher Educators with respect to Select Sub-sample

\begin{tabular}{|l|l|l|l|l|l|}
\hline Sub-Variable & N & Mean & SD & t-value & Level of significance \\
\hline Male & 89 & 105.57 & 21.807 & & \multirow{2}{*}{ S at 0.01 level } \\
\hline Female & 217 & 112.98 & 17.209 & 3.155 & \\
\hline Arts & 86 & 103.14 & 15.729 & \multirow{2}{*}{4.272} & S at 0.01 level \\
\hline Science & 144 & 112.14 & 17.544 & & \\
\hline Tamil & 136 & 109.04 & 19.114 & \multirow{2}{*}{1.482} & LS \\
\hline English & 170 & 112.26 & 18.712 & & \\
\hline UG & 126 & 111.41 & 21.840 & & \\
\hline PG & 180 & 110.42 & 16.643 & & \\
\hline Married & 127 & 110.37 & 15.354 & & \\
\hline Un married & 179 & 111.15 & 21.138 & & \\
\hline Rural & 193 & 109.28 & 19.297 & \multirow{2}{*}{1.870} & LS \\
\hline Urban & 113 & 113.46 & 18.062 & & \\
\hline
\end{tabular}




\begin{tabular}{|l|l|l|l|l|l|}
\hline Sub-Variable & N & Mean & SD & t-value & Level of significance \\
\hline Male & 89 & 105.57 & 21.807 & 2155 & S at 0.01 level \\
\hline Joint & 101 & 110.77 & 18.353 & \multirow{2}{*}{0.1270} & LS \\
\hline Nuclear & 205 & 110.85 & 19.250 & & \\
\hline
\end{tabular}

S-Significant \& LS - Least Significant T- Table Value $1.98(0.05) \& 2.30(0.01)$

From the above Table.2, it is shown that gender, nature of subject has significant influence. Medium of instruction, educational qualification, marital status, location and type of family has least significant influence over the awareness of e-learning among Prospective Teacher Educators.

\section{Recommendations}

Based on the findings and conclusions that emerged from the analysis of data collected from the Prospective Teacher Educators. The investigator makes the following recommendation with the view to enhancing the e-learning awareness. Changes in curriculum may be attempted with a view to providing continuous updating of e-learning. Pre-service computer training like online courses, online assignment submission may be encouraged so as to make them proficient with computer and internet skills. The training should be more practical and reliable.

\section{Conclusion}

The overall findings suggested that the level of e-learning awareness among prospective teacher educators was average. But it is not enough that prospective teacher educators are the future pillars who are going to train the prospective student teachers in very near future. In this techno savvy environment and era of digitalization, the role of prospective teacher educators with average e-learning awareness is not enough to face the present student generation. In the $21^{\text {st }}$ century, many factors are bringing strong forces to bear on the adoption of e-learning in education and contemporary trends suggest that large scale changes in the way education is planned and delivered as a consequence of the opportunities and affordance of e-learning. It is believed that the use of e-learning in education can increase access to learning opportunities. It can help to enhance the quality of education with advanced teaching methods, improve learning outcomes and enable reform or better management of education system. The prospective teacher educators must give more opportunities to use the website and learn more through online. Nowadays the post graduate students are given more seminar classes where they can use the technology in the classrooms for teaching a concept. This makes the students to gather information through e-learning contents and to relevant up to date their knowledge with information gathered and also to interact with the others regarding the concepts through online. 


\section{References}

[1] Dikshit, H.P. Power K.B. and Tiwari M.D. (2002). ICT enabled Education, New Delhi: Association of Indian Universities.

[2] Golden, S. A. R. (2011). Problems and Prospectus of Distance Education. Quality Enhancement In Distance Education For Life Long Learning, 1(1), 343-344.

[3] Golden, S. A. R. (2011). Strategy For Success Of Human Beings:-Time Management.

[4] Golden, S. A. R. (2016). RURAL STUDENTS' ATTITUDE TOWARDS ENGLISH AS MEDIUM OF INSTRUCTION IN HIGHER EDUCATION - AN ANALYSIS. International Journal of Research, 3(Special Issue - 16), 1-10.

[5] Kothari. C.R. (1994). Research Methodology, Methods and Techniques. New Delhi: Willey Eastern Company.

[6] Panch. Ramalingam., (2006) Education and Information Technology, ASC, Pondicherry.

[7] Paul F. Morrill, and et al., (1986) Computers in Education, New Jersey Prentice Hall.

[8] Regi, S. B., \& Golden, S. A. R. (2014). A Study On Educational Loan Availed By Students In Trichy City. JOURNAL OF INTERNATIONAL ACADEMIC RESEARCH FOR MULTIDISCIPLINARY (JIARM), 2(1).

[9] Vanaja. M., and Rajasekar., (2006). Educational Technology and Computer Education, New Delhi; Neel Kamal Publications Pvt. Ltd. 